\title{
How the participants of a Yoga Prana Vidya YPV) eye camp experienced vision improvements: A case study
}

\author{
V S Nanduri ${ }^{*}$, Chaitra $\mathrm{N}^{2}$ \\ ${ }^{1}$ Consultant, ${ }^{2}$ YPV Healer, Yoga Prana Vidya Ashram, Tamil Nadu, India \\ *Corresponding Author: V S Nanduri \\ Email: vsnanduri@yahoo.com
}

\begin{abstract}
Introduction: Yoga Prana Vidya (YPV) system based on ancient yogic practices, is an integrated approach known from experience to heal diverse human diseases and sicknesses holistically. This case study presents the outcomes of vision improvements of participants through Yoga Prana Vidya (YPV) healing techniques by conducting a two-week eye healing camp at Bangarpet, Karnataka.

Materials and Methods: This is a case study method going into details of how the YPV eye camp was conducted. The YPV team collaborated with eye doctors of the local Government hospitals who screened and helped to identify a sample of 27 eye patients. YPV healers performed healing daily on each patient. In addition, the patients were trained to practice some YPV techniques on daily basis. Patient feedback reports were also taken at the end of the intervention.

Results: After receiving healing, vision improved for 23 participants from $80 \%$ to $100 \%$ within 5 to 10 days of healing. Seven of them could read without spectacles. However, for one patient cylindrical and spherical values were found to be higher than at intake, which needed further investigations. Three participants could not participate fully in the camp and discontinued for personal reasons.

Conclusion: It is observed that the YPV process caused other positive effects also besides improvements in vision for most of them, indicating the holistic nature of YPV healing. Participants who regularly attended forgiveness prayer and breathing exercises had better results. A participant who had been suffering from insomnia reported getting quality deep sleep.
\end{abstract}

Keywords: Eye disorders, Vision impairments, Optometric measurements, Yoga Prana Vidya Healing.

\section{Introduction}

Yoga Prana Vidya (YPV) is a non-drug and non-touch healing system that has been a proven and established discipline in healing various ailments, physiological and psychological. ${ }^{1}$ It is used as complementary to main stream medicine systems such as Allopathy, Ayurveda, Homeopathy etc., and also used as standalone process in the treatment of certain health conditions. Its popularity in the recent times is attributable to satisfaction expressed by those healed and confirmed by their family members. YPV is also known to heal psychological sicknesses as well as physical sicknesses (authors, 2019a; 2019b) 2,3 $^{2}$

\section{Literature Survey: Vision Problems}

Imperfections in the focusing power of the eye are called refractive errors. There are three primary types of refractive errors: myopia, hyperopia and astigmatism. Combinations of myopia and astigmatism or hyperopia and astigmatism are common. With age, presbyopia and cataracts can also impair vision (Lasersight, 2019). ${ }^{4}$

Persons with myopia, or near-sightedness, have clear close up vision but have more difficulty seeing distant objects. In Hyperopia, or farsightedness, near vision blurs first and then distance at a later stage. Astigmatism is a distortion of the image on the retina caused by irregularities in the cornea or lens of the eye. Presbyopia is a condition that everyone develops at some point. People over the age of forty suffer from increased difficulty in reading.

Canadian scientists are of the opinion that healthy eyes can prevent the development of dementia in individuals (Arpita De, 2018). ${ }^{5}$ In the literature we come across common eye health problems which are treated through mainstream medicine and also healed through the use of alternative medicine such as Yoga Prana Vidya in this case, called an energy medicine. 
Many age-related vision problems stem from a gradual loss of flexibility and tone in the eye muscles, which get locked into habitual patterns and lose their ability to focus at different distances. To maintain existing good eyesight or to improve fuzzy eyesight, evidence suggests that yoga may have a solution (Ruiz, 2007). ${ }^{6}$ The core exercises taught by the late celebrated ophthalmologist William $\mathrm{H}$. Bates are yogic in nature and Bates claimed he could improve visual perception with palming, eyeball rotations, and vision shifting.

Dry eye syndrome is caused by a chronic lack of sufficient lubrication and moisture on the surface of the eye. Its consequences range from subtle but constant irritation to inflammation of the anterior (front) tissues of the eye. Dry eyes are also called keratitis sicca, which means reduced quality or quantity of tears. Similarly Keratoconjunctivitis sicca refers to eye dryness affecting both the cornea and the conjunctiva. Causes of dry eye syndrome may include hormonal changes, natural aging process, side effect of many medications such as blood pressure medications, Parkinson's medications and birth control pills and environmental conditions. Dry, dusty or windy climate may increase risk of dry eyes.

Blurry vision is always a concern for diabetes, whether transient or longer lasting. It may be indicative of blood sugar being too high or too low, and should be checked immediately (Pietrangelo, 2016). ${ }^{7}$ Although blurry vision may be a result of diabetes, there are other reasons you might have blurry vision. Some common causes include:

Dry eyes

Near-sightedness

Low blood pressure

Inflammation, or infection

Certain prescription drugs

If you spend a lot of time in front of a computer monitor or handheld electronic device, you may find your vision getting blurry. This is called digital eye strain. Your eyes may be feeling the strain of poor lighting or the glare of the digital screen. If you're not seated at the proper viewing distance, that can add to the problem. Other signs of digital eye strain include headache, dry eyes, and neck or shoulder pain. You may be able to correct the problem by adjusting your workspace and taking frequent breaks.

Blurred vision can also be a symptom of certain immune system disorders, such as multiple sclerosis and lupus. Treating the disease may ease symptoms like blurry vision.

Symptoms of eye infections may include redness, itching, swelling, discharge, pain, or problems with vision. Treatment depends on the cause of the infection and may include compresses, eye drops, creams, or antibiotics. (Medlineplus, 2016). ${ }^{8}$

Amblyopia is the medical term used when the vision in one of the eyes is reduced because the eye and the brain are not working together properly. The eye itself looks normal, but it is not being used normally because the brain is favouring the other eye. This condition is also sometimes called lazy eye (National Eye Institute, 2013). ${ }^{9}$

Squint [Strabismus] is a condition in which there is a misalign-ment of the eyes (Dr. Agarwal's Eye Hospital, 2019). ${ }^{\mathbf{1 0}}$ In other words, the two eyes are pointed in different directions. One eye may be looking straight ahead while the other is turned inward, outward, upward or downward. Muscles of the eye control movements of the eye. If one muscle is stronger than the other, the eye will be turned towards that direction. This is how a squint is formed. To treat this, one has to weaken the stronger muscle and strengthen the weaker muscle.

Yoga for healthy eyes can help improve their functioning and even overcome various eye-related problems such as short-sightedness and longsightedness. Our eyes are one of the most important organs in the human body, allowing us to view the world around us. However, we often neglect to take care of them, but yoga exercises for eyes aim to improve various disorders that affect eye muscles (Andre, 2017). ${ }^{11}$

Benefits of yoga for vision improvement has been studied by some investigators. ${ }^{\mathbf{1 2}-14}$ Relaxation appears to be the single most important element of eye health. In an experiment applying the muscle relaxant curare to the eyes, patients experienced dramatic eyesight improvement (Ruiz, 2007). ${ }^{6}$ 


\section{Methods and Materials}

This is a case study method andexamined all aspects of the YPV eye camp conducted and made qualitative assessment of the outcomes of vision and other conditions of the selected patients. The camp organisers obtained ethics clearance of the Institutional Ethics Committee of the Host Institution for field work.

\section{The eye healing camp \& screening of patients}

The Eye camp was conducted from 5 December 2018 to $20^{\text {th }}$ December 2018 in Bangarpet in Kolar District of Karnataka (India). The camp organiser requested and obtained help of an Ophthalmologist from the local government hospital to work with the YPV team collaboratively for taking and recording sight measurements at the beginning, middle and end of the camp.

\section{Camp demographics}

A total of 27 eye-screened persons were registered for healing at the camp. There were 18 females and 9 males. Age of the participants ranged from 6 years to 64 years. The children were 7 and remaining 20 were adults. Out of the 27 registered, 24 participants completed full programme and gave final feedback. The other three participants could not complete the full programme because of personal reasons, and their data is incomplete and not included in this study.

\section{Induction and orientation day programme}

On the first day of the camp, induction and orientation of duration $2 \frac{1}{2}$ hours was conducted with brief introduction, and informing participants about the camp objectives and the schedule of activities. The participants were also educated to understand basic Eye Anatomy and health and YPV system. Participants learned Rhythmic yogic breathing, Forgiveness prayer, Metta meditation, Eye strengthening exercises, and Positive affirmations. Three demo healings were also done (with before and after vision readings)

\section{Daily Healing programme}

Daily program in the healing camp started with a session of about 45 minutes of practicing of the following YPV techniquesby all participating patients and YPV practitioners.

1. Rhythmic yogic breathing

2. Forgiveness prayer

3. Metta meditation

4. Eye strengthening exercises

5. Positive affirmations

Subsequently individual participants were given healing sessions by the healers to treat following ailments by YPV healing processes.

1. Astigmatism

2. Myopia

3. Presbyopia

Hyper myopia

1. Blurred vision

2. Eye infection

3. Computer vision syndrome

4. Dryness of eyes

5. Squint

6. Lazy eye

The process of healing included sensing the condition of relevant chakras, cleansing, energising and securing the energies of the chakras relevant with eyes. This process was repeated day after day to a point when the patient expressed satisfaction and recorded measurements corroborated by the eye doctors.

\section{Results}

After receiving healing for 5 to 10 days, vision improved from $80 \%$ to $100 \%$ for 23 persons healed. Seven of them could read without spectacles. However, one patient in whose case cylindrical and spherical values were found to be higher than at intake, was referred for further investigation. A participant, who had been suffering from insomnia prior to attending this healing camp, reported that he is getting quality deep sleep. Five participants have stopped using spectacles after 3 days of healing.

The case summaries of the 23 participants are presented in Tables 1 \& 2 . 
Table 1: Case summaries

\begin{tabular}{|c|c|c|c|c|}
\hline S. No & Patient & $\begin{array}{l}\text { PRE-YPV } \\
\text { symptoms }\end{array}$ & $\begin{array}{c}\text { POST-YPV Camp Healing } \\
\text { effects }\end{array}$ & Effects after 3 months of Healing \\
\hline 1 & $\begin{array}{l}\text { Boy } 6 \\
\text { years } \\
\text { age }\end{array}$ & $\begin{array}{l}\text { Eyes blinking, } \\
\text { difficulty in reading } \\
\text { even with glasses. } \\
\text { Myopia, } \\
\text { Astigmatism, dry eye }\end{array}$ & $\begin{array}{l}\text { Before healing, eye blinking was } \\
\text { too much whole day. After } \\
\text { healing blinking reduced } 40 \% \text {. } \\
\text { He used to read the books from } \\
\text { very close, now he is able to } \\
\text { read from quite good distance. }\end{array}$ & $\begin{array}{l}\text { Now he is able to read from quite good } \\
\text { distance. Before he was not confident } \\
\text { to dance and play without using } \\
\text { spectacles. Now he is very confident in } \\
\text { involving in activities without wearing } \\
\text { glasses. }\end{array}$ \\
\hline 2 & $\begin{array}{l}\text { Girl } 16 \\
\text { years } \\
\text { age }\end{array}$ & Myopia,Astigmatism & $\begin{array}{l}\text { Vision improved by } 80 \% \text {. Neck } \\
\text { pain and shoulder pain stopped. } \\
\text { Able to see without glasses for } \\
\text { up to } 12 \text { hours. Able to see from } \\
\text { third floor in college clearly, } \\
\text { before it was not so. }\end{array}$ & Sameeffects maintained. \\
\hline 3 & $\begin{array}{l}\text { Female } \\
47 \\
\text { years } \\
\text { age }\end{array}$ & $\begin{array}{l}\text { Myopia, } \\
\text { Astigmatism, } \\
\text { watering of eyes due } \\
\text { to infection }\end{array}$ & $\begin{array}{l}\text { Eye watering stopped. Back pain } \\
\text { reduced by } 90 \%\end{array}$ & Sameeffects maintained. \\
\hline 4 & $\begin{array}{l}\text { Boy } 15 \\
\text { years } \\
\text { age }\end{array}$ & $\begin{array}{l}\text { Myopia, } \\
\text { Astigmatism, blurred } \\
\text { vision }\end{array}$ & $\begin{array}{l}\text { Blurred vision reduced by } 80 \% \text {, } \\
\text { could see the black board in } \\
\text { class clearly. knee swelling } \\
\text { subsided completely (had this } \\
\text { due to fall), feeling more } \\
\text { energetic in classroom }\end{array}$ & $\begin{array}{l}\text { Could see the black board in class } \\
\text { clearly. Not wearing glasses }\end{array}$ \\
\hline 5 & $\begin{array}{l}\text { Male } \\
43 \\
\text { years } \\
\text { age }\end{array}$ & $\begin{array}{l}\text { Myopia, } \\
\text { Astigmatism, } \\
\text { refractive error }\end{array}$ & $\begin{array}{l}\text { Blurring reduced, getting good } \\
\text { sleep after many years, } \\
\text { emotionally feeling good }\end{array}$ & $\begin{array}{l}\text { Same effects maintained as previously } \\
\text { stated. }\end{array}$ \\
\hline 6 & $\begin{array}{l}\text { Female } \\
42 \\
\text { Years } \\
\text { age }\end{array}$ & $\begin{array}{l}\text { Compound } \\
\text { (hyper } \quad \text { w-) } \\
\text { astigmatism }\end{array}$ & $\begin{array}{l}\text { Blurred vision completely } \\
\text { healed. Could read newspaper } \\
\text { without glasses. } 70 \% \text { knee pain } \\
\text { reduced. }\end{array}$ & No blurring of vision \\
\hline 7 & $\begin{array}{l}\text { Female } \\
21 \\
\text { years } \\
\text { age }\end{array}$ & Myopic Astigmatism & $\begin{array}{l}\text { Blurring reduced by } 55 \% \text {. Could } \\
\text { read without glass. Headache } \\
\text { completely healed. Could view a } \\
\text { movie in the big screen without } \\
\text { glasses. Not wearing glasses } \\
\text { since healing started. }\end{array}$ & $\begin{array}{l}\text { Same report maintained. Feeling very } \\
\text { healthy. }\end{array}$ \\
\hline 8 & $\begin{array}{l}\text { Male } \\
18 \\
\text { years } \\
\text { age }\end{array}$ & $\begin{array}{l}\text { Myopia, } \\
\text { Astigmatism, } \\
\text { refractive error }\end{array}$ & $\begin{array}{l}\text { Could stay without glass for } 2 \text { to } \\
3 \text { hours. Happy with the healing, }\end{array}$ & $\begin{array}{l}\text { No further improvements. Mentally } \\
\text { feeling good. Continuing daily } \\
\text { meditation with mother. }\end{array}$ \\
\hline 9 & $\begin{array}{l}\text { Female } \\
19 \\
\text { years } \\
\text { age }\end{array}$ & $\begin{array}{l}\text { myopia, astigmatism, } \\
\text { refractive error }\end{array}$ & $\begin{array}{l}75 \% \text { eye irritation healed. } \\
\text { Brightness in the eyes increased. } \\
\text { Could see without glasses whole } \\
\text { day. Even cansee projector for } \\
\text { the whole day. }\end{array}$ & $\begin{array}{l}\text { Eye irritation completely healed. } \\
\text { Feeling good with meditation \& } \\
\text { forgiveness practice }\end{array}$ \\
\hline 10 & $\begin{array}{l}\text { Female } \\
37\end{array}$ & $\begin{array}{ll}\text { Kerato, } & \text { refractive } \\
\text { error } & \end{array}$ & $\begin{array}{l}\text { Vision improved. Physically and } \\
\text { mentally relaxed and active. }\end{array}$ & $\begin{array}{l}\text { Not much change seen in eye } \\
\text { condition. Physically and mentally }\end{array}$ \\
\hline
\end{tabular}




\begin{tabular}{|l|l|l|l|l|}
\hline & $\begin{array}{l}\text { years } \\
\text { age }\end{array}$ & $\begin{array}{l}\text { Physical pains completely } \\
\text { healed. Could do all physical } \\
\text { exercises easily compared to } \\
\text { before. }\end{array}$ & $\begin{array}{l}\text { relaxed and active. Physical pains } \\
\text { completely healed }\end{array}$ \\
\hline 11 & $\begin{array}{l}\text { Female } \\
21 \text { years } \\
\text { age }\end{array}$ & $\begin{array}{l}\text { myopia, astigmatism, } \\
\text { refractive error }\end{array}$ & $\begin{array}{l}\text { Eyes are relaxed, Could see } \\
\text { without spectacles for 3 hours. } \\
\text { Blurredness reduced. Physically } \\
\text { and mentally feeling energized, } \\
\text { feeling better in all sense. }\end{array}$ & $\begin{array}{l}\text { Eyes are relaxed, Could see without } \\
\text { spectacles for few hours. Blurredness } \\
\text { reduced. Physically and mentally } \\
\text { feeling energized, feeling better in all } \\
\text { sense. }\end{array}$ \\
\hline
\end{tabular}

Table 2: Case summaries (Continued)

\begin{tabular}{|c|c|c|c|c|}
\hline S. No & Patient & PRE-YPV symptoms & $\begin{array}{l}\text { POST-YPV Camp Healing } \\
\text { effects }\end{array}$ & $\begin{array}{c}\text { Effects after } 3 \text { months of } \\
\text { camp Healing }\end{array}$ \\
\hline 12 & $\begin{array}{lll}\begin{array}{l}\text { Female } \\
\text { age }\end{array} & & \text { years } \\
\end{array}$ & Myopia, unreadable & $\begin{array}{l}\text { Did not wear glasses after } \\
\text { healing. Could stay without } \\
\text { glasses for all work. Not } \\
\text { wearing glasses for last } 13 \\
\text { days. }\end{array}$ & $\begin{array}{l}\text { Did not wearing glasses } \\
\text { after healing. Could stay } \\
\text { without glasses for all } \\
\text { work. Not wearing } \\
\text { glasses from } \\
\begin{array}{l}\text { December. } \\
\text { forgiveness }\end{array} \\
\text { affirmations daily }\end{array}$ \\
\hline 13 & Male 25 years age & $\begin{array}{l}\text { Compound myopic } \\
\text { astigmatism, } \\
\text { unreadable }\end{array}$ & $\begin{array}{l}\text { Very comfortable without } \\
\text { glasses for whole day. Could } \\
\text { stay without glasses for the } \\
\text { whole day. Not been } \\
\text { wearing glasses for last } 14 \\
\text { days. }\end{array}$ & $\begin{array}{l}\text { Very comfortable without } \\
\text { glasses for whole day. } \\
\text { Could stay without } \\
\text { glasses for the whole day. } \\
\text { Not been wearing glasses } \\
\text { from last December }\end{array}$ \\
\hline 14 & $\begin{array}{l}\text { Female } 46 \text { years } \\
\text { age }\end{array}$ & $\begin{array}{l}\text { Myopia, Astigmatism } \\
\text { refractive error }\end{array}$ & $\begin{array}{l}\text { Sinusitis reduced. } 70 \% \\
\text { breathing improved. Body } \\
\text { pain completely healed. } \\
\text { Periods pain better }\end{array}$ & $\begin{array}{l}\text { Very comfortable without } \\
\text { glasses for whole day. } \\
\text { Could stay without } \\
\text { glasses for the whole day. } \\
\text { Not been wearing glasses } \\
\text { from last December. }\end{array}$ \\
\hline 15 & Girl 14 years age & Lack of clear vision & $\begin{array}{l}\text { Vision and brightness of eye } \\
\text { improved. Could stay } \\
\text { without glasses for two } \\
\text { hours without blurring. } \\
\text { Emotionally calmer, } \\
\text { physically feeling strong and } \\
\text { getting good sleep. }\end{array}$ & $\begin{array}{l}\text { Vision and brightness of } \\
\text { eye improved. Could stay } \\
\text { without glasses for two } \\
\text { hours without blurring. } \\
\text { Emotionally calmer, } \\
\text { physically feeling strong } \\
\text { and getting good sleep. } \\
\text { Periods got normalized. } \\
\text { No further dysmenorrhea } \\
\text { experienced. }\end{array}$ \\
\hline 16 & Male 23 years age & Blurred vision & $\begin{array}{l}\text { Could see positive changes } \\
\text { in vision. stress reduced }\end{array}$ & $\begin{array}{l}\text { : No further improvement } \\
\text { noticed }\end{array}$ \\
\hline 17 & Boy 15 years age & $\begin{array}{l}\text { Lack of vision clarity } \\
\text { with } \\
\text { glasses.Notcomfortable } \\
\text { with glasses. }\end{array}$ & $\begin{array}{l}\text { Blurredness reduced, Could } \\
\text { stay without glasses for few } \\
\text { hours. There is more vision } \\
\text { clarity with glasses which } \\
\text { was not there before. Now }\end{array}$ & $\begin{array}{l}\text { Blurredness reduced, } \\
\text { Could stay without } \\
\text { glasses for few hours. } \\
\text { There is more vision } \\
\text { clarity with glasses which }\end{array}$ \\
\hline
\end{tabular}




\begin{tabular}{|c|c|c|c|c|}
\hline & & & $\begin{array}{l}\text { very comfortable with glass. } \\
\text { Feeling energetic in class } \\
\text { and physical exhaustion } \\
\text { completely healed. }\end{array}$ & $\begin{array}{l}\text { was not there before. } \\
\text { Now very comfortable } \\
\text { with glasses. Feeling } \\
\text { energetic in class (no } \\
\text { sleepy days in school) and } \\
\text { physical exhaustion } \\
\text { completely healed. }\end{array}$ \\
\hline 18 & Girl 10 years age & $\begin{array}{lr}\text { Eye } & \text { infection. She } \\
\text { used } & \text { prescription } \\
\text { glasses } & \end{array}$ & $\begin{array}{l}\text { In School she didn't used } \\
\text { glasses, able to see black } \\
\text { board easily. Eye infection } \\
\text { completely healed. Could } \\
\text { stay without glasses for } \\
\text { whole day. Not used glasses } \\
\text { since 14 days }\end{array}$ & $\begin{array}{l}\text { In School she didn't used } \\
\text { glasses, able to see black } \\
\text { board easily. Eye } \\
\text { infection completely } \\
\text { healed. Could stay } \\
\text { without glasses for whole } \\
\text { day now from December. }\end{array}$ \\
\hline 19 & $\begin{array}{lll}\begin{array}{l}\text { Female } \\
\text { age }\end{array} & & \text { years } \\
\end{array}$ & $\begin{array}{l}\text { Refractive Error, } \\
\text { Myopic astigmatism }\end{array}$ & $\begin{array}{l}\text { Blurredness substantially } \\
\text { reduced. Headache healed. } \\
\text { Eye irritation reduced by } \\
20 \% \text {. Headache completely } \\
\text { healed. Emotionally } \\
\text { stronger. Could stay without } \\
\text { glasses since 5 days. }\end{array}$ & $\begin{array}{lr}\begin{array}{l}\text { Blurring } \\
\text { reduced. }\end{array} & \text { substantially } \\
\text { Headache } & \text { healed } \\
\text { completely, } & \text { not } \\
\text { encountered } & \text { since } \\
\text { December. Eye } & \text { irritation } \\
\text { reduced by } & 50 \% \text {. } \\
\text { Emotionally } & \text { stronger. } \\
\text { Could stay } & \text { without } \\
\text { glasses December. Doing } \\
\text { regular PPM breathing, } \\
\text { forgiveness. }\end{array}$ \\
\hline 20 & $\begin{array}{lll}\begin{array}{l}\text { Female } \\
\text { age }\end{array} & & \text { years } \\
\end{array}$ & Blurredness of Vision & $\begin{array}{l}\text { Blurring reduced. Leg pain } \\
\text { reduced. } 50 \% \text { reduction in } \\
\text { the size of the growth } \\
\text { around thyroid gland. } \\
\text { (dominantly seen) }\end{array}$ & $\begin{array}{l}\text { Leg pain reduced. } 50 \% \\
\text { reduction in the size of } \\
\text { the growth around thyroid } \\
\text { gland. (dominantly seen) }\end{array}$ \\
\hline 21 & Male 18years age & Blurredness of Vision & $\begin{array}{l}\text { Eye condition improved. } \\
\text { Can manage multiple task } \\
\text { without taking stress. Could } \\
\text { stay calmer. }\end{array}$ & $\begin{array}{l}\text { Can manage multiple task } \\
\text { without taking stress. } \\
\text { Could stay calmer. No } \\
\text { further changes with eye } \\
\text { condition. }\end{array}$ \\
\hline 22 & $\begin{array}{lll}\begin{array}{l}\text { Female } \\
\text { aged }\end{array} & & \text { years } \\
\end{array}$ & Blurredness of vision & $\begin{array}{l}\text { Vision blurredness healed by } \\
45 \% \text {. Body pain } 90 \% \\
\text { reduced, getting good sleep. } \\
\text { Could achieve good bladder } \\
\text { control. }\end{array}$ & $\begin{array}{l}\text { Vision blurredness healed } \\
\text { by } 45 \% \text {. Body pain } 90 \% \\
\text { reduced, feeling better } \\
\text { with physical strength. } \\
\text { Getting good sleep after } \\
\text { healing, continuing with } \\
\text { occasional healings. } \\
\text { Could achieve good } \\
\text { bladder control. Does } \\
\text { Rhythmic } \\
\text { breathing daily }\end{array}$ \\
\hline 23 & $\begin{array}{l}\text { Female } 34 \text { years } \\
\text { aged }\end{array}$ & $\begin{array}{l}\text { Refractive Error, } \\
\text { Myopic astigmatism }\end{array}$ & $\begin{array}{l}\text { Able to read newspaper } \\
\text { without glasses comfortably. } \\
\text { I could see a movie without }\end{array}$ & $\begin{array}{l}\begin{array}{l}\text { Able to read newspaper } \\
\text { glasses }\end{array} \\
\text { without } \\
\text { comfortably. I could do }\end{array}$ \\
\hline
\end{tabular}




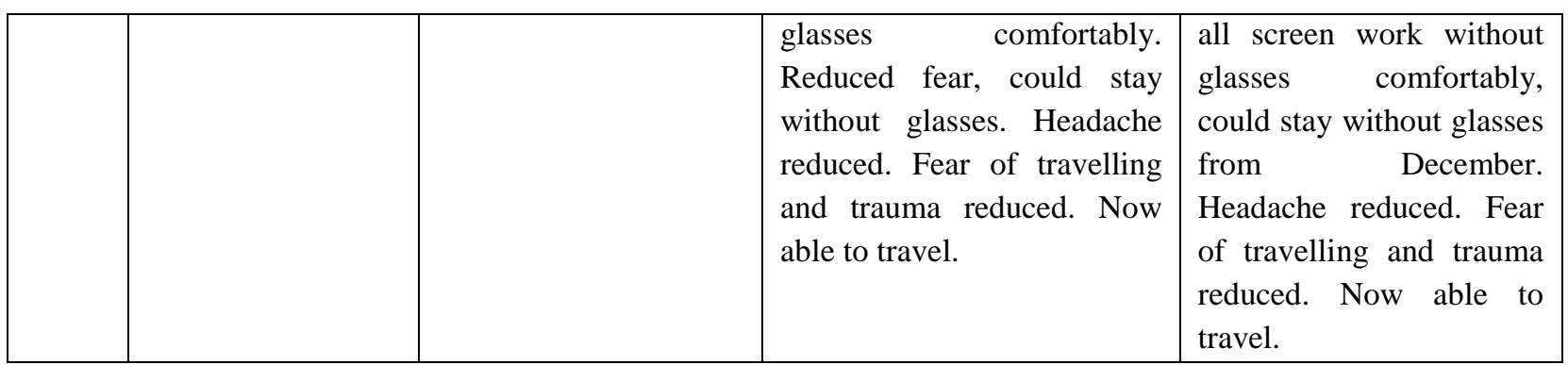

\section{What went well: From participants' experiences}

From the feedback interviews given by the participants at the end of the camp, the following responses were recorded.

1. "more relaxed after healing"

2. "greater mental clarity"

3. "improved ability to focus"

4. "feeling more energetic while at school/work"

5. "feeling stronger"

6. "marked reduction in pain"

7. " $100 \%$ improvement in blurred vision"

8. "Better sleep at night"

9. "Eye itching completely cured"

10. "Excessive blinking of eyes normalized"

\section{Other outcomes of the camp}

As a spinoff of this camp, the team was invited to conduct similar camps in two other towns. Many of the participants expressed interest in learning YPV healing. New healers who involved in camp, and gaining overall experience in healing camp and seeing its success, they showed interest in Arhat yoga \& higher classes. The principal organiser, also the YPV instructor, gained hands-on experience in clearly documenting the results of eye healing camp and introduced YPV Sadhana app to camp participants.

\section{Discussion}

In this two-week eye camp study, the Yoga Prana Vidya healing methods and techniques were applied on patients screened by ophthalmologists thereby the results and outcomes were verifiable. Also, patient feedback reports at the end of the camp corroborated with outcomes. In addition, follow up enquiries conducted on the patients and their relatives 3 months after the camp ended, enabled to assess the improvements and other outcomes sustained over a period.

\section{Conclusions}

It is found from this study that the YPV process of healing worked well to improve vision problems for most participants. It also noted other positive effects besides improvements in vision, indicating the holistic nature of YPV healing. Some participants who regularly attended forgiveness prayer and breathing exercises had better results. Further studies may be conducted with targeted research methodologies for generating wider evidence base in the successful use of YPV for healing eye disorders.

\section{Acknowledgements}

The authors express sincere thanks to Sri Rama Trust for allowing to using copyright terms "Yoga Prana Vidya ${ }^{\odot}$ and YPV ${ }^{\odot}$,, and for giving permission to use camp data in the preparation of this study report.

\section{Source of Funding}

None.

\section{Conflict of Interest}

None.

\section{References}

1. Yoga Prana Vidya Research. (2019). "A compendium of Theory, Research and practice of Yoga Prana Vidya". Unpublished document, YPV Ashram, Sri Ramana Trust, Thally, Tamilnadu, India.

2. Authors. (2019a). "Diabetes Management and Control Using Yoga Prana Vidya (YPV) Healing System”. J Biol Life Sci 2019;10(2):106-20.

3. Authors. (2019b). "A study into successful treatment of some difficult Medical cases using Yoga Prana Vidya (YPV) Healing System as alternative medicine". Int J Sci Eng Res 2019;10(7):882-7. 
4. Lasersight. (2019). "Vision Problems". Available from https://www.lasik.com.au/eye-conditions/visualimpairment/ 06 January 2019.

5. Arpita De, (2018). "Healthy Eyes and Teeth can Prevent Dementia". Available from https://www.onlymyhealth.com/healthy-eyes-teeth-canprevent-dementia-1310718928 on 5 Jan 2018.

6. Ruiz, FD, (2007). "Yoga for Your Eyes: Simple Asanas to Improve Your Vision”. Available 5 Jan 2019 from https://www.yogajournal.com/lifestyle/insight-for-soreeyes

7. Pietrangelo, (2016). "Diabetes and Blurry vision: What you need to know". Available from https://www.healthline.com/health/diabetes/blurry-vision\#1 06 January 2019.

8. Medlineplus, (2016). "Eye Infections". Available from https://medlineplus.gov/eyeinfections.html 06 January 2019.

9. National Eye Institute, (2013). “Amblyopia”Available from https://nei.nih.gov/health/amblyopia/ 06 January 2019.

10. Agarwal's Eye Hospital, (2019)."Squint”. Availablefrom http://www.dragarwal.com/specialties/squint-treatment-forchildren-adults/ 06 January 2019.
11. Andre (2017). "Yoga for eyes". Available from https://www.belmarrahealth.com/yoga-eyes-easy-eye-yogaposes-improve-vision/ 06 January 2019.

12. Gopinathan G, Dhiman KS, Manjusha R. (2012). "A clinical study to evaluate the efficacy of Trataka Yoga Kriya and eye exercises (non-pharmocological methods) in the management of Timira (Ammetropia and Presbyopia)". Ауи 2012;33(4):543-6.

13. Sankalp, Dada T, Yadav RK, Faiq MA. (2018). "Effect of yoga-based ocular exercises in lowering of intraocular pressure in glaucoma patients: An affirmative proposition". Int J Yoga [serial online] 2018 [cited 2019 Mar 6];11:23941. Available from: http://www.ijoy.org.in/text.asp?2018/11/3/239/240327

14. Jois, SN, Prasad NK. (2018). "Pranic Healing for partially blind: A case study". Res J Health Sci 2018;6(1) Jan/March 2018.

How to cite this article: Nanduri VS, Chaitra N. How the participants of a Yoga Prana Vidya YPV) eye camp experienced vision improvements: A case study. $J$ Community Health Manag 2019;6(4):139-46. 